\title{
Differences in Effectiveness of Antibacterial Power Between Cocoa Peel Extract (Theobroma cocoa L.) and Benzalkonium Chloride 0.1\% Against Staphylococcus aureus (In Vitro)
}

\author{
Tamara Yuanita, ${ }^{1}$ Mohammed Alaqsha Brysoul Ceson, ${ }^{2}$ Agus Subiyanto ${ }^{1}$ \\ ${ }^{1}$ Staff Department of Conservative Dentistry, Faculty of Dental Medicine, Universitas Airlangga, Surabaya, Indonesia \\ ${ }^{2}$ Undergraduate Student of Dental Medicine Faculty, Universitas Airlangga, Surabaya, Indonesia
}

\begin{abstract}
Background: Staphylococcus aureus is a gram-positive bacteria play a role in the formation of dental biofilm which is causing dental caries. During tooth preparation, to stop the growth of bacteria, a cavity cleaning agent is given using a chemical, namely Benzalkonium Chloride (BAC) 0.1\%, but BAC has disadvantages including allergic reactions, tolerant microbes, and resistance. Therefore, it is hoped that there will be herbal ingredients that can be used as an alternative. Cocoa peel extract has active compounds of tannins, flavonoids, alkaloids, terpenoids, and saponins which have antibacterial concentration $6 \%$ according to safe concentrations. Purpose: To explain the difference in the effectiveness of the antibacterial power of 6\% cocoa peel extract and $0.1 \%$ BAC against Staphylococcus aureus (in vitro). Methods: This study was a laboratory experimental in vitro with the posttest only control group design. Using the diffusion method for Staphylococcus aureus that divided into two parts, $6 \%$ cocoa peel extract and $0.1 \%$ BAC. Each petri dish was given disc paper dripped with $0.01 \mathrm{ml}$ of each test material, then incubated for two days and observed the diameter of the inhibition zone. Results: The average diameter of the inhibition zone formed in the 6\% cacao peel extract was 11.5288 mm and BAC 0.1\% was $18.2925 \mathrm{~mm}$ against Staphylococcus aureus. Conclusion: There was a significant difference in the effectiveness of antibacterial power $(p<0.05)$ between $6 \%$ cacao peel extract (Theobroma cacao L.) and $0.1 \%$ BAC against Staphylococcus aureus (In Vitro).
\end{abstract}

Keywords: Cocoa peel extract; Benzalkunium chloride; Staphylococcus aureus

Correspondence: Tamara Yuanita, Conservative Dentistry Department, Faculty of Dental Medicine, Universitas Airlangga. J1 Mayjen. Prof. Dr. Moestopo No. 47, Surabaya 60132, Indonesia. Email: tamara-y@fkg.unair.ac.id

\section{INTRODUCTION}

The prevalence of dental caries (tooth decay and tooth ache) according to Basic Health Research (Riskesdas) in Indonesia reaches $45.3 \%{ }^{1}$ Bacteria that can cause dental caries include Streptococcus mutans, Lactobacilli, Streptococcus gordonii, Streptococcus sanguinis, dan Staphylococcus aureus (S. aureus). ${ }^{2-4}$

$S$. aureus is a gram-positive bacteria that is aerobic and facultative anaerobic. The presence of $S$. aureus in the oral cavity is very easy to find and varies with a caries rate of $24-84 \%$ in the oral cavity of healthy adults. ${ }^{2,5} \mathrm{~S}$. aureus can cause oral mucositis, periodontitis, peri-implantitis, and endodontic infection. ${ }^{6} S$. aureus plays a role in the formation of dental biofilms which are one of the factors causing dental caries. ${ }^{7}$

Cavity cleanser is a material that can clean, wet, and simultaneously disinfect microorganisms in tooth preparation procedures. The requirements needed as a cavity cleansing agent are to have a low level of toxicity or no toxicity to pulp cells and do not interfere with or inhibit the adhesion of the restoration material used as a fill. ${ }^{8}$ The presence of residual bacteria in the smear layer after deep tooth preparation long time can result in secondary caries. ${ }^{9}$ Cavity cleansers commonly used in dentistry are chlorhexidine (CHX), $\mathrm{NaOCl}$, Benzalkonium chloride (BAC), and iodine. ${ }^{10}$

Benzalkonium chloride (BAC) is a mixture of alkyl benzyl dimethyl ammonium chloride and is a cationic agent nitrogen containing quaternary ammonium groups with broad antimicrobial activity. BAC-based cavity cleanser are easy to obtain and are often used in foreign countries such as the United States because they are considered safe, but the use of BAC in Indonesia is still rarely used. The most common BAC-based cavity cleanser is Tubulicid Red which contains $1.0 \%$ sodium fluoride, $0.1 \%$ benzalkonium chloride, and $0.2 \%$ EDTA. ${ }^{10,11}$ BAC in high concentrations causes allergic reactions and toxic effects. The use of BAC as an antimicrobial can cause tolerant and resistant microbes to several types of bacteria including Campylobacter coli, 
Salmonella enterica serovar Virchow, and Escherichia coli O157. ${ }^{10,12}$

Herbal ingredients have been the object of research and are continuously being developed because they have benefits for human health. Herbal ingredients in dentist and medical practice have been used for thousands of years and continue to grow because they have high antimicrobial activity, biocompatibility, anti-inflammatory, analgesic, and antioxidants, one of which is found in the cocoa peel. ${ }^{13}$

Indonesia has abundant cocoa (Theobroma cacao L.) fruit plantations. ${ }^{14}$ In 2012, the total area for cocoa plantations was $1,732,954$ hectares with a total production of 936,266 tons. The processing of cocoa peel will leave a large amount of fruit skin waste and become industrial waste products that are not utilized optimally or are left to rot in the plantation area which ultimately pollutes the surrounding environment such as causing an unpleasant odor. ${ }^{15}$ Cocoa peel contains phenolic compounds and flavonoid. Polyphenol compounds contain cinamic acid, tannins, pyrogallol, quercetin, resorcinol, and epicatecin-3 which contain antibacterial substances. ${ }^{16}$ In addition, the skin of cocoa peel contains active compounds such as anthocyanidins, catechins, and leukoantocyanidins. These bioactive compounds are known to have antibacterial properties. $^{17}$

Mulyatni et al., 2016 proved that the peel extract of the Hybrid type (Upper Hibrida Amazon) has the potential as an antibacterial agent against Escherichia coli, Bacillus subtilis, and S. aureus with concentrations of $0 \%$ (control), $1 \%$ respectively; $2 \% ; 4 \% ; 8 \% ; 16 \% ; 32 \%$; and $64 \%$. Growth of $S$. aureus can be inhibited most effectively at $8 \%$ Minimum Inhibitory Concentration (MIC) ${ }^{17}$ Fitriana et al, 2019 using the MTT assay method on BHK-21 fibroblast cells (Baby Hamster Kidney-21) that cocoa peel extracts with concentrations below $6.25 \%$ such as $1.56 \%$ and $3.25 \%$ are classified as safe with less cell death. than $50 \%$. Whereas in the cocoa bark extract above a concentration of $6.25 \%$, more than $50 \%$ of cell death occurred, which means it is toxic. ${ }^{18}$

From the results of this study, the researchers used Forastero pod skin extract with three concentrations below $6.25 \%$, namely $6 \%, 5 \%$, and $4 \%$ as a preliminary study and then the most effective concentration was taken, namely $6 \%$ for comparison with the cleanser. cavity BAC concentration $0.1 \%$.

\section{MATERIALS AND METHODS}

This type of research is an in vitro laboratory experimental study with the research design of The Post Test Only Control Group Design and using a sample of $S$. aureus bacteria stocks obtained from the Research Center of the Faculty of Dentistry, Airlangga University, Surabaya Indonesia.

In this study, Forastero cocoa was obtained from Sumedang, West Java, Indonesia. $1 \mathrm{~kg}$ of cacao peel are washed, drained, and cut into 1-2 $\mathrm{mm}$ pieces. The pieces of cocoa peel were dried by aerating for three days at room temperature and followed by drying in an oven at $40^{\circ} \mathrm{C}$ for six hours. Dry cocoa peel are made into powder by crushing them in a blender. 40 grams of cocoa peel powder is put into a maceration extractor and $400 \mathrm{ml}$ of $70 \%$ ethanol solvent is added ${ }^{19}$ and stirred several times, let stand for 24 hours in the erlenmeyer jar. Then stir until homogeneous using a shaker for 24 hours. Furthermore, the maceration results were filtered using Whatman filter paper no. 41, so that the maserate results are obtained.

Solvent (ethanol) evaporation in macerate until it is free from ethanol solvent using a Rotary Vacuum Evaporator to obtain pure cocoa peel extract. Taking $2 \mathrm{ml}$ of concentrated extract was then carried out dilution to a concentration of $4 \%, 5 \%$, and $6 \%$ for preliminary research and $6 \%$ for actual research.

S. aureus cultures were taken from $S$. aureus bacteria stocks using sterile osse and planted on BHIB (Brain Heart Infusion Agar) media. Subsequently incubated for 16-18 hours at $37^{\circ} \mathrm{C}$. Culture matching with McFarland standards, then thinning it to reach McFarland standard of 0.5 or equivalent to $1.5 \times 108 \mathrm{CFU} / \mathrm{ml}$ to obtain bacteria with a certain concentration. Taking $S$. aureus bacteria from BHIB which had equalized its turbidity with McFarland 0.5 solution.

S. aureus cultures were grown on nutrient media to use a cotton swab using the swab method. Drop 6\% cocoa peel extract and $0.1 \%$ Benzalkonium chloride as much as $10 \mu \mathrm{l}$ disc paper. Place the disc paper that has been dripped with $6 \%$ cocoa peel extract and $0.1 \%$ benzalkonium chloride on each of the divided agar surfaces. Observation on each treatment will produce inhibition zones that have varying diameters and irregular shapes. The longest diameter and the shortest diameter formed are measured using a caliper in millimeters ( $\mathrm{mm})$, then add up and then divide by two to obtain a mean.

\section{RESULTS}

The research began with the manufacture of extracts of cocoa peel and phytochemical tests at the Balai Penelitian dan Konsultasi Industri (BPKI) Surabaya. The following is a Table 1 of compounds from the phytochemical test results of the cocoa peel extract.

The purpose of this study was to determine and explain the difference in the effectiveness of antibacterial activity between $6 \%$ cocoa peel extract and $0.1 \%$ BAC against $S$. aureus bacteria (in vitro) by diffusion method. This study

Table 1. Phytochemical test results of cocoa peel extract

\begin{tabular}{lc}
\hline Content & Percentage \\
\hline Flavonoid & $3.05 \%$ \\
Alkaloid & $5.02 \%$ \\
Tanin & $4.15 \%$ \\
Saponin & $4.08 \%$ \\
Terpenoid & $2.11 \%$ \\
\hline
\end{tabular}


used two treatment groups, namely the cocoa peel extract concentration group of $6 \%$ and BAC $0.1 \%$. The $6 \%$ cacao peel extract concentration is the most effective and safe concentration. There were 16 replications in a row in the $6 \%$ cocoa peel extract and $0.1 \% \mathrm{BAC}$ and the results were shown in the following figure.

The data in Table 2, Table 3, Figure 1, and Figure 2 show that there is a difference in the inhibition zone between the $6 \%$ cocoa peel extract inhibition zone group

Table 2. Table of research values in $\mathrm{mm}$ antibacterial extract of $6 \%$ cocoa peel extract and $0.1 \%$ BAC against $S$. Aureus bacteria which were replicated 16 times

\begin{tabular}{lcc}
\hline No. & $\begin{array}{c}\text { Benzalkonium chloride } \\
0.1 \%(\mathrm{~mm})\end{array}$ & $\begin{array}{c}\text { Cocoa peel extract } \\
6 \%(\mathrm{~mm})\end{array}$ \\
\hline 1 & 18.40 & 11.40 \\
2 & 18.00 & 11.55 \\
3 & 18.20 & 11.35 \\
4 & 18.35 & 11.55 \\
5 & 18.40 & 11.60 \\
6 & 18.15 & 11.55 \\
7 & 18.55 & 11.70 \\
8 & 18.35 & 11.50 \\
9 & 18.20 & 11.35 \\
10 & 18.10 & 11.45 \\
11 & 18.29 & 11.50 \\
12 & 18.40 & 11.65 \\
13 & 18.55 & 11.60 \\
14 & 18.00 & 11.65 \\
15 & 18.45 & 11.53 \\
16 & 18.29 & 11.53 \\
\hline
\end{tabular}

and the $0.1 \%$ BAC group which means the $6 \%$ cacao peel extract inhibition zone is narrower compared to the BAC $0.1 \%$ group. Data analysis begins with the KolmogorovSmirnov test to determine whether the data is normally distributed or not.

The $\mathrm{p}$ value in the treatment group of $6 \%$ cacao pod peel extract was smaller than 0.05 and BAC $0.1 \%$ was greater than 0.05 , which means the data were not normally distributed. Data is normally distributed if the significance value (Asymp. Sig) or $p$ value is greater than 0.05 . Furthermore, statistical analysis was carried out using Levene's test to test the homogeneity of the data.

Based on the results in the Levene's test table, it was found that the $\mathrm{p}$ value was 0.042 , which was smaller than 0.05 , which means that the data for the treatment group was not homogeneous or the variants of the two data groups were not the same in the $6 \%$ cocoa peel extract and $0.1 \%$ BAC.

The next statistical test is the Mann-Whitney test to determine whether there is a difference in the mean (means) of the two non-parametric unpaired treatment groups.

Based on the results in the Mann-Whitney test table, it was found that the $\mathrm{p}$ value was less than 0.05 , which means that the hypothesis was accepted, which meant that there was a significant difference between the results of the inhibition zone of $6 \%$ cacao peel extract and $0.1 \%$ BAC.

Tabel 3. The mean and standard deviation values of inhibition zone diameter $(\mathrm{mm})$ antibacterial of $6 \%$ cocoa peel extract and $0.1 \%$ BAC

\begin{tabular}{lccc}
\hline Group & $\mathrm{N}$ & Mean of inhibition zone diameter (mm) & Standard deviation (SD) \\
\hline $6 \%$ Cocoa peel extract group & 16 & 11.5288 & 0.10601 \\
$0.1 \%$ Benzalkonium chloride group & 16 & 18.2925 & 0.17210 \\
\hline
\end{tabular}

Table 4. Data normality test results using the KolmogorovSmirnov test.

\begin{tabular}{|l|c|}
\hline Treatment group & $\mathrm{p}$ value \\
\hline $6 \%$ Cocoa peel extract group & 0.007 \\
\cline { 2 - 2 } $0.1 \%$ Benzalkonium chloride group & 0.200 \\
\hline
\end{tabular}

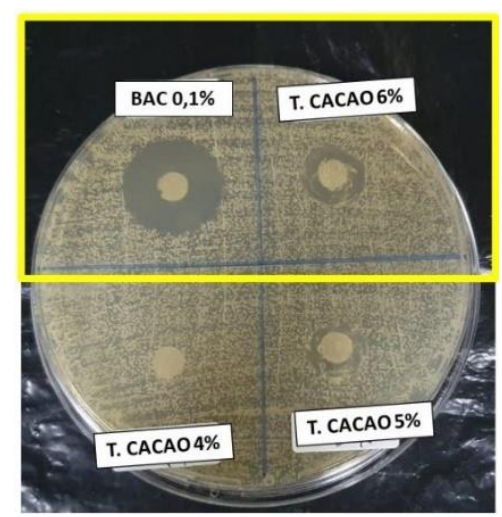

Figure 1. Results of Differences in Inhibition Zone of $6 \%$ Cocoa Peel Extract and $0.1 \%$ BAC (in the yellow box) Against $S$. aureus bacteria which were replicated 16 times.
Table 5. Homogeneity test results using Levene's test

\begin{tabular}{|l|c|}
\hline Treatment group & p-value \\
\hline $6 \%$ Cocoa peel extract group & 0.042 \\
$0.1 \%$ Benzalkonium chloride group & \\
\hline
\end{tabular}

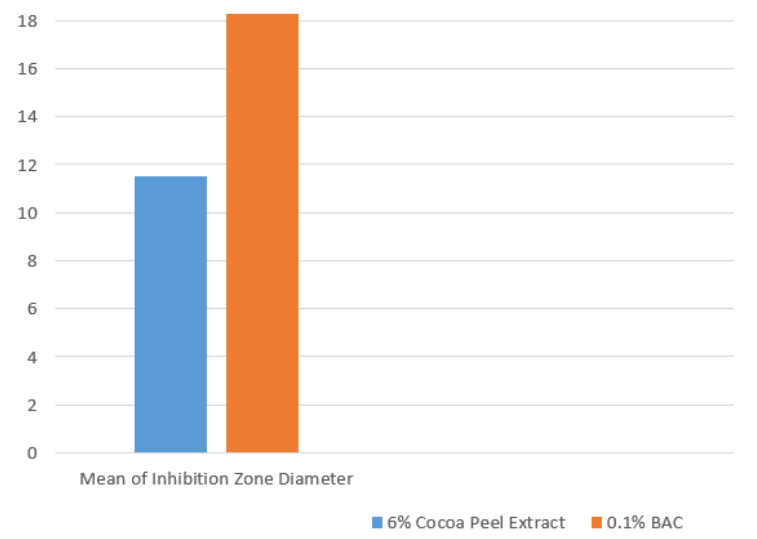

Figure 2. Bar Chart of the Mean Value of Inhibition Zone Diameter $(\mathrm{mm})$ Antibacterial Power of $6 \%$ Cocoa Peel Extract and $0.1 \%$ BAC. 
Tabel 6. Results of the mean difference test using the MannWhitney test.

\begin{tabular}{|l|l|}
\hline Treatment group & p-value \\
\hline $6 \%$ Cocoa peel extract group & 0.000 \\
$0.1 \%$ Benzalkonium chloride group & \\
\hline
\end{tabular}

\section{DISCUSSION}

In this study, the bacteria used was $S$. aureus which was obtained from the Research Center of the Faculty of Dentistry, Airlangga University, Surabaya. The type of cocoa peel selected in this study is Forastero. Forastero type was chosen because it contains anthocyanin compounds, contains the most polyphenols and is easy to obtain compared to other types of cocoa. Extracts of cocoa peel and obtained a concentration of $6 \%$, then continued with the actual research with a total of 16 sample replications.

The presence of $S$. aureus bacteria varies with a caries rate of $24-84 \%$ in the oral cavity of healthy adults. ${ }^{2}$ S. aureus plays a role in the formation of dental biofilms which is one of the factors causing dental caries. ${ }^{7}$ The remaining bacteria present after the preparation process can affect the level of the success of a dental restoration. Bacteria left during the preparation process can cause pulp irritation, secondary caries, and sensitivity after restoration. ${ }^{10}$ Antibacterial cavity cleaners are needed to remove debris and bacteria that can prevent failure of fill restorations caused by residual bacteria in tooth preparation. ${ }^{21}$

$\mathrm{BAC}$ is a nitrogen cationic agent containing quaternary ammonium groups with broad antimicrobial activity. ${ }^{10} \mathrm{BAC}$ as a cavity cleaner is often used in dentistry and is commercial in nature. such as Campylobacter coli, Salmonella enterica serovar Virchow, and Escherichia coli O157.12 In addition, BAC solutions have been reported to cause local irritation to the orofacial mucosa and at high concentrations can cause allergic reactions and toxic effects. ${ }^{10}$

This study used antibacterial content against $S$. aureus bacteria from the extract of the cocoa peel with a concentration of $6 \%$ and BAC $0.1 \%$. In this study, $70 \%$ ethanol was used as a solvent for the extraction of compounds from the cocoa peel. The compound in a material will dissolve in a solvent that has the same properties. One of the compounds in cocoa peel that is polar is flavonoids. Therefore, a polar solvent is needed in order to produce maximum extract material and good effectiveness from the cocoa peel. $70 \%$ ethanol is a more polar solvent than $96 \%$ ethanol and is more non-polar than $50 \%$ ethanol so that flavonoids tend to dissolve in $70 \%$ ethanol. Phytochemical tests were carried out to determine the content contained in the extract of the cocoa peel. The content of cocoa peel extract obtained from phytochemical tests was saponins $4.08 \%$, flavonoids $3.05 \%$, tannins $4.15 \%$, terpenoids $2.11 \%$, alkaloids $5.02 \%$. The five ingredients of the cocoa peel extract contain antibacterial properties in accordance with the supporting theory.

Furthermore, the actual research was carried out using the diffusion method, namely the antibacterial power between the $6 \%$ cacao peel extract compared to the BAC antibacterial power of $0.1 \%$. $10 \mu \mathrm{l}$ of each test material was taken and then dropped on disc paper that was already located on the nutrient agar medium and divided into two group zones. Within 24 hours a zone of inhibition will form around the test material. This means that the $6 \%$ cocoa peel extract and $0.1 \%$ BAC have antibacterial power against $S$. aureus.

The results obtained from the antibacterial test mean and standard deviation of inhibition zone diameter (Table 3.) $6 \%$ antibacterial extract of cocoa peel had a diameter of $11.5288 \mathrm{~mm}$ and a BAC of $0.1 \%$. has a diameter of 18.2925 $\mathrm{mm}$. From the test results, it was obtained that the mean diameter of the inhibition zone formed in the cocoa peel extract group was $6 \%$ smaller than the BAC group of $0.1 \%$. This means that the $6 \%$ peel extract has lower antibacterial power compared to $0.1 \%$ BAC.

The antibacterial power of BAC is $0.1 \%$ which is higher than that of $6 \%$ cacao peel because BAC has amphiphilicity, which is a hydrophobic region (long carbon chain alkyl) which destabilizes the pathogen's surface which interacts with negatively charged components and penetration of hydrophobic long pubescent groups into the hydrophobic bacterial bilayer which causes cells to leak and lysis. ${ }^{22}$ In addition, BAC has been shown to have extensive antimicrobial activity. ${ }^{10}$ In addition, quaternary ammonium compounds in BAC cause changes in cell membrane permeability and disruption of membrane load distribution which leads to leakage of cytoplasmic components which will result in bacterial death. ${ }^{23}$

BAC works actively on the cell surface by destroying the fat on the bacterial cell membrane, resulting in the leakage of components in the cell and the bacteria becoming dead. ${ }^{24}$ In addition, BAC can kill vegetative forms of bacteria and microorganisms. ${ }^{25}$

In other literature, it is explained that BAC can damage the cell's phospholipid bilayer, then penetration into the cell and essential proteins undergo denaturation and inactivation of metabolic enzymes needed by bacterial cells. Finally, the bacterial cell cannot continue the metabolic process in the cell. Proteins that make up cells and damaged enzymes then cause bacterial cell death. ${ }^{26} \mathrm{BAC}$ after penetrating into the cell wall, then reacts with the cytoplasmic membrane (which is composed of phospholipids and proteins). This causes disruption of the cytoplasmic membrane and the contents of the cytoplasm will leak. Changes in the structure and arrangement of amino acids will occur due to this reaction, so that the genetics in the DNA chain will be damaged and unbalanced and then the bacterial cell becomes lysis. ${ }^{27}$

Cocoa peel extract contains 3.05\% flavonoid active compounds which produce complex bonds with bacterial cell walls formed by flavonoid compounds and a decrease in cell wall permeability and damage to bacterial cell membranes because they are lipophilic. ${ }^{28}$ In addition, flavonoids contain active catechins. which has bactericidal properties, namely by denaturing proteins in bacteria. Whereas procyanidin can activate or damage genetic material from bacteria and anthocyanins have antibacterial properties. ${ }^{29}$ 
The $4.08 \%$ saponin active compound can hydrolyze the cell wall and eliminate the semi permeability due to damage to the cell membrane, so that water and enzyme substances cannot be selected in and out. This results in disruption of cell metabolism, so that the formation of ATP in cell growth is inhibited. Cell death will occur if this process continues. ${ }^{30}$ In addition, saponins can also cause protein and enzyme leakage from within cells due to saponin ${ }^{31}$ compounds. Hydrolyzed cell walls can cause membrane surface pressure to decrease resulting in cell lysis. ${ }^{32}$

The active compound of tannins $4.15 \%$ in the extract of the cocoa peel forms a bond with the bacterial cell wall then activates the ability to stick to bacteria and inhibits bacterial growth. In both types of extracts, steroid content cannot be detected because some steroids are nonpolar and semipolar. Therefore, solvents having nonpolar and semipolar properties in the isolation process can be used. Cocoa peel extract has antimicrobial properties and further research can be developed to determine the ability of the cocoa peel extract to inhibit the growth of pathogenic fungi and pathogenic bacteria. ${ }^{28}$

The active terpenoid compound $2.11 \%$ acts as an antibacterial by reacting with the lipid fraction of the bacterial plasma membrane and changes in membrane permeability and lysis of the intracellular material due to the formation of a hollow lipid bilayer. ${ }^{28}$

The alkaloid active compound $5.02 \%$ is antibacterial by disturbing the peptidoglycan constituent components in bacteria, then the cells die because the cell wall layer is not formed completely. In addition, there is an inhibitory process in the formation of cell walls so that it will cause cell lysis which can cause cells to die. ${ }^{33}$

The $6 \%$ concentration of cocoa peel extract still has antibacterial content as evidenced by the presence of an inhibition zone on the disc paper. Cocoa peel extract is one of the most researched herbal ingredients and has been shown to have antibacterial properties. Herbal ingredients continue to be developed because they have health benefits for humans and have better biocompatibility in body tissues than BAC $0.1 \%$, which is a pure chemical. BAC has side effects, namely allergies, toxic at concentrations of more than $0.1 \%$, and has caused a lot of resistance. Therefore, a concentration of $6 \%$ cacao peel extract can be considered as a candidate for cavity cleaning which has good antibacterial and biocompatibility properties for the body.

Data from the results of the Mann-Whitney statistical test showed that the inhibition zone diameter between groups of $6 \%$ cacao peel extract compared to $0.1 \%$ BAC against $S$. aureus bacteria had a significant difference in results. A significant difference was shown in the antibacterial results of the $6 \%$ cacao peel extract with a diameter of $11.5288 \mathrm{~mm}$ and a BAC of $0.1 \%$. has a diameter of $18.2925 \mathrm{~mm}$.

\section{CONCLUSION}

There is a significant difference between the $6 \%$ cacao peel extract compared to $0.1 \%$ BAC against $S$. aureus bacteria.
Cocoa peel extract with a concentration of $6 \%$ has lower antibacterial effectiveness compared to BAC $0.1 \%$ against S. aureus bacteria.

\section{REFERENCES}

1. Riset Kesehatan Dasar (Riskesdas). 2018. Laporan Nasional Riskesdas 2018. Jakarta: Kementerian Kesehatan Republic Indonesia - Bahan Penelitian Dan Pengembangan Kesehatan, p.204

2. McCormack MG, Smith AJ, Akram AN, Jackson M, Robertson D, Edwards G. Staphylococcus aureus and the oral cavity: An overlooked source of carriage and infection? Am J Infect Control. 2015;43(1):35-7.

3. Valm AM. The Structure of Dental Plaque Microbial Communities in the Transition from Health to Dental Caries and Periodontal Disease. J Mol Biol. 2019;431(16):295769.

4. Li W, Qi M, Sun X, Chi M, Wan Y, Zheng X, et al. Novel dental adhesive containing silver exchanged EMT zeolites against cariogenic biofilms to combat dental caries. Microporous Mesoporous Mater. 2020;110113.

5. Diyantika D, Mufida DC. Perubahan Morfologi Staphylococcus aureus Akibat Paparan Ekstrak Etanol Biji Kakao ( Theobroma cacao ) secara In Vitro ( The Morphology Change of Staphylococcus Aureus Caused by Ethanolic extracts of Cocoa Beans ( Theobama Cacao ) in Vitro ). 2014;2(2):337-45.

6. Manisha, D., Abdullah, A.M.S., Zobayda FH, Nanda B, Amrita P, Md. MM, et al. Characterization of Staphylococcus aureus isolated from human dental infection. African J Microbiol Res. 2019;13(14):273-8.

7. Marsh PD, Zaura E. Dental biofilm: ecological interactions in health and disease. J Clin Periodontol. 2017;44:S12-22.

8. Setianingrum ID, Suardita K, Subiyanto A, Agustin D. Perbedaan daya pembersih kavitas saponin ekstrak kulit manggis (Garcinia (The difference of $0,78 \%$ saponin from mangosteen pericarp extract and $6 \%$ citric acid for cleanliness of cavity). 2017;7(1):6-11.

9. Nadalia Malika Bilqis, Isyana Erlita DKTP. Daya Hambat Ekstrak Bawang Dayak (Eleutherine palmifolia (L.) Merr.). Dentin J Kedokt Gigi. 2018;2(1):26-31.

10. Bin-Shuwaish MS. Effects and effectiveness of cavity disinfectants in operative dentistry: A literature review. J Contemp Dent Pract. 2016;17(10):867-79.

11. Elkassas Dr. DW, Fawzi EM, El Zohairy A. The effect of cavity disinfectants on the micro-shear bond strength of dentin adhesives. Eur J Dent. 2014;8(2):184-90.

12. Pereira BMP, Tagkopoulos I. Benzalkonium chlorides: Uses, regulatory status, and microbial resistance. Appl Environ Microbiol. 2019;85(13):1-13.

13. Nugroho SW, Rukmo M, Prasetyo EA, Yuanita T. Antibakteri Ekstrak Kulit Buah Kakao ( Theobroma cacao ) sanguinis. 2019;9(1):19-21.

14. Yumas M. Pemanfaatan Limbah Kulit Ari Biji Kakao (Theobroma cacao L) Sebagai Sumber Antibakteri Streptococcus mutans. (Utilization of Cocoa Beans Epidermis Waste (Theobroma cacao L) as Antibacterial Streptococcus mutans). J Ind Has Perkeb. 2017;12(2):7-20.

15. Purnamawati H, Utami B. Pemanfaatan Limbah Kulit Buah Kakao (Theobroma cocoa L) Sebagai Adsorben Zat Warna Rhodamin B. Pros Semin Nas Fis dan Pendidik Fis. 2014;5(1):12. 
16. Budaraga IK, Putra DP. Liquid Smoke Antimicrobial Test of Cocoa Fruit Peel Against Eschericia Coli and Staphylococcus Aureus Bacteria. IOP Conf Ser Earth Environ Sci. 2019;365(1).

17. Mulyatni AS, Budiani A, Taniwiryono D. Aktivitas antibakteri ekstrak kulit buah kakao (Theobroma cacao L.) terhadap Escherichia coli, Bacillus subtilis, dan Staphylococcus aureus. E-Journal Menara Perkeb. 2016;80(2):77-84.

18. Fajarina Fitriani, Agus Subiwahjudi, Adioro Soetojo TY. Sitotoksisitas Ekstrak Kulit Kakao (Theobroma cacao) Terhadap Kultur Sel Fibroblas BHK-21. 2018;9(1):54-65.

19. Riwanti P, Izazih F, Amaliyah A. Pengaruh Perbedaan Konsentrasi Etanol pada Kadar Flavonoid Total Ekstrak Etanol 50,70 dan 96\% Sargassum polycystum dari Madura. J Pharm Anwar Med. 2018;2(2):35-48.

20. Martono B. Plasma Nutfah Tanaman Kakao Morphological Characteristics And. 2013;15-28.

21. Agrawal, N. Effect OfCavity Disinfection With Chlorhexidine On Microleakage Of Composite Restorations Using Total Etch And Self Etch And Self Etch Single Bottle Adhesive Systems -Vitro Study. International J. Of Healthcare \& Biomedical Research. 2013. 2(1): 4347.

22. Chen L, Suh BI, Yang J. Antibacterial dental restorative materials: A review. Am J Dent. 2018;31(Sp Is B):6B-12B.

23. Arias-Moliz MT, Ruiz-Linares M, Cassar G, FerrerLuque CM, Baca P, Ordinola-Zapata R, et al. The effect of benzalkonium chloride additions to AH Plus sealer. Antimicrobial, physical and chemical properties. J Dent. 2015;43(7):846-54.

24. Susanti, M. 'Efektivitas Tisu Basah Antiseptik Untuk Menurunkan Jumlah Bakteri Tangan' Jurnal Bio Educatio, Volume 2, Nomor 2, Oktober 2017, hlm. 79-82.

25. Hidayat, S., Ferdiansyah, R., Juniarto, AD. JSTFI Indonesian Journal of Pharmaceutical Science and Technology. Vol.III,
No 1, Januari 2014. https://ejournal.stfi.ac.id/index.php/jstfi/ article/view/31/23

26. Penido A, Mendes P, Campos I, Mendes L. Malaysian Journal of Microbiology. Malays J Microbiol. 2013;9(2):166-75.

27. Wahyuni VH, Khotimah S, Liana DF, Biologi PS, Untan F. Perbandingan Efektivitas antara Gel Hand Sanitizer dan Tisu Basah Antiseptik terhadap Jumlah Koloni Kuman di Tangan Latar Belakang Penyakit infeksi adalah penyakit yang disebabkan oleh mikroba patogen dan bersifat sangat dinamis . Mikroba sebagai mahluk h. J Cerebellum. 2017;3:808-19.

28. Rachmawaty, Mu'nisa A, Hasri. Analisis fitokimia ekstrak kulit buah kakao (Theobroma cacao L.) sebagai kandidat antimikroba. Proc Natl Semin. 2017;667-70.

29. Hafidhah N, Hakim RF, Fakhrurrazi F. Pengaruh ekstrak biji kakao (Theobroma cacao L.) terhadap pertumbuhan enterococcus faecalis pada berbagai konsentrasi. J Caninus Denstistry. 2017;2(2):92-6.

30. Husna Fa, Sulasmi Es, Witjoro A, 2016, Uji Aktivitas Antibakteri Ekstrak Metanol Ental Muda Diplazium Esculentum (Retz.) Swartz Terhadap Pertumbuhan S. aureus Dan Escherichia Coli Secara In Vitro, Malang; Jurnal Universitas Negeri Malang

31. Madduluri S, Rao Kb, Sitaram B, 2013, In Vitro Evaluation Of Antibacterial Activity Of Five Indigenous Plants Extract Against Five Bacterial Pathogens Of Human. Tamil; International Journal of Pharmacy and Pharmaceutical sciences.

32. Hassan SM, Haq AU, Byrd JA, Cartwright AL, Bailey CA, 2010, Haemolytic and antimicrobial activities of saponinrich extracts from guar meal, Ismallia; Elsevier

33. Lamothe RG, Michell G, Gattuso M, Diarra MS, Malouin F, Bouarab K, 2009, Plant Antimicrobial Agents and Their Effects on Plant and Human Pathogens, Quebec; International Journal Of Molecullar Science. 